\title{
Fabrication and Properties of Plasma Resistant YAS Frit-coated $\mathrm{Al}_{2} \mathrm{O}_{3}$
}

\author{
Eui-Keun Park, Hyun-Kwuon Lee \\ Department of Advanced Materials Science and Engineering/Kumoh National Institute of Technology \\ 61 Daehak-ro (yangho-dong), Gumi, Gyeongbuk 730-701, Korea, Republic of \\ Czarkhan86@naver.com; hklee@kumoh.ac.kr
}

\begin{abstract}
Recently, as a realization of ultrafine circuit wafer process in semiconductor industry, highly plasma resistant ceramic materials have been continuously required for its severe etching process. Bulk $\mathrm{Y}_{2} \mathrm{O}_{3}$ ceramics and $\mathrm{Y}_{2} \mathrm{O}_{3}$-coated ceramic components by plasma thermal spray process have been paid great attentions as candidates. However, application of the bulk $\mathrm{Y}_{2} \mathrm{O}_{3}$ materials is highly expensive; furthermore, surface failure of $\mathrm{Y}_{2} \mathrm{O}_{3}$-coated ceramic components by plasma thermal spray process causes serious problems such as contamination and low production yield. In order to solve this problem should be studied on the surface reinforcement of ceramics consistently.

In this study, YAS $\left(\mathrm{Y}_{2} \mathrm{O}_{3}-\mathrm{Al}_{2} \mathrm{O}_{3}-\mathrm{SiO}_{2}\right)$ frit was fabricated by melting method. Then, fabricated YAS frit was coated on the surface of $\mathrm{Al}_{2} \mathrm{O}_{3}$ ceramics by simple coating process for improved plasma resistance. Effect of processing parameters on $\mathrm{YAS}_{\mathrm{A}}$ frit-coated $\mathrm{Al}_{2} \mathrm{O}_{3}$ fabrication and effect of YAS frit composition on the plasma resistance were studied, and tried to be optimized. Plasma resistance of YAS frit-coated $\mathrm{Al}_{2} \mathrm{O}_{3}$ ceramics was improved with increasing $\mathrm{Y}_{2} \mathrm{O}_{3}$ content in YAS system; its plasma resistance was 6 times higher than quartz, 2 times than $\mathrm{Al}_{2} \mathrm{O}_{3}$ and a half of $\mathrm{Y}_{2} \mathrm{O}_{3}$.
\end{abstract}

Keywords: $\mathrm{YAS}, \mathrm{Y}_{2} \mathrm{O}_{3}-\mathrm{Al}_{2} \mathrm{O}_{3}-\mathrm{SiO}_{2}$, coating, plasma resistance

\section{Introduction}

Etching and deposition equipment are necessarily in use for surface micromachining or removal of impurities in semiconductor or display industry. Recently, as a realization of ultrafine circuit wafer process in semiconductor industry, highly plasma resistant ceramic materials have been continuously required for its severe etching process [1].

The typical plasma resistant ceramic is oxide material such as $\mathrm{Al}_{2} \mathrm{O}_{3}, \mathrm{Y}_{2} \mathrm{O}_{3}$, etc. Especially, $\mathrm{Y}_{2} \mathrm{O}_{3}$ has been reported to have highly plasma resistance [2]. Bulk $\mathrm{Y}_{2} \mathrm{O}_{3}$ ceramics and $\mathrm{Y}_{2} \mathrm{O}_{3}$-coated ceramic components by plasma thermal spray process have been paid great attentions as candidates [3]. However, application of the bulk $\mathrm{Y}_{2} \mathrm{O}_{3}$ materials is highly expensive owing to high price of the $\mathrm{Y}_{2} \mathrm{O}_{3}$ materials itself; furthermore, surface failure of $\mathrm{Y}_{2} \mathrm{O}_{3}$-coated ceramic components by plasma thermal spray process causes serious problems such as contamination and low production yield[2,4].

This study going to develop the plasma resistant ceramic materials by simple coating process on the surface of alumina ceramics using $\mathrm{YAS}\left(\mathrm{Y}_{2} \mathrm{O}_{3}-\mathrm{Al}_{2} \mathrm{O}_{3}-\mathrm{SiO}_{2}\right)$ frit that include $\mathrm{Y}_{2} \mathrm{O}_{3}$. YAS glass is widely used in structural and functional ceramic field because of their promising high corrosion resistance, mechanical and optical properties [7].

In this study, YAS frit was coated on the surface of $\mathrm{Al}_{2} \mathrm{O}_{3}$ ceramics to solve contamination and high-cost of the semiconductor and display manufacturing process as fabricated low-cost plasma resistant materials. For its fabrication, YAS frit was designed by decreased or increased content of each oxide such as $\mathrm{Y}_{2} \mathrm{O}_{3}, \mathrm{Al}_{2} \mathrm{O}_{3}$ and $\mathrm{SiO}_{2}$. And then, Effect of processing parameters on YAS frit-coated $\mathrm{Al}_{2} \mathrm{O}_{3}$ fabrication and effect of YAS frit composition on the plasma resistance were studied, and tried to be optimized.

\section{Experimental}

\subsection{Raw materials}

Commercial powders of $\mathrm{Y}_{2} \mathrm{O}_{3}$ (>99.99\%, Kojundo Korea Co.,LTD, Japan), $\mathrm{Al}_{2} \mathrm{O}_{3}$ (>99.99\%, Kojundo Korea Co.,LTD, Japan), $\mathrm{SiO}_{2}(>99.99 \%$, SukgyungAT, Korea) were used as raw materials. 


\subsection{Sample preparation}

The raw materials were mixed according to each compositions (Fig. 1), and homogenized by ball milling with $\mathrm{Al}_{2} \mathrm{O}_{3}$ balls as medium and ethanol as solvent. Then, the slurry was dried to get the batch powder for YAS frit. Each batch powder was loaded into an alumina crucible and heated in an electric furnace. After then, the sample was naturally cooled down in the furnace. Fabricated YAS frit was coated on the surface of $\mathrm{Al}_{2} \mathrm{O}_{3}$ ceramics for improved plasma resistance.

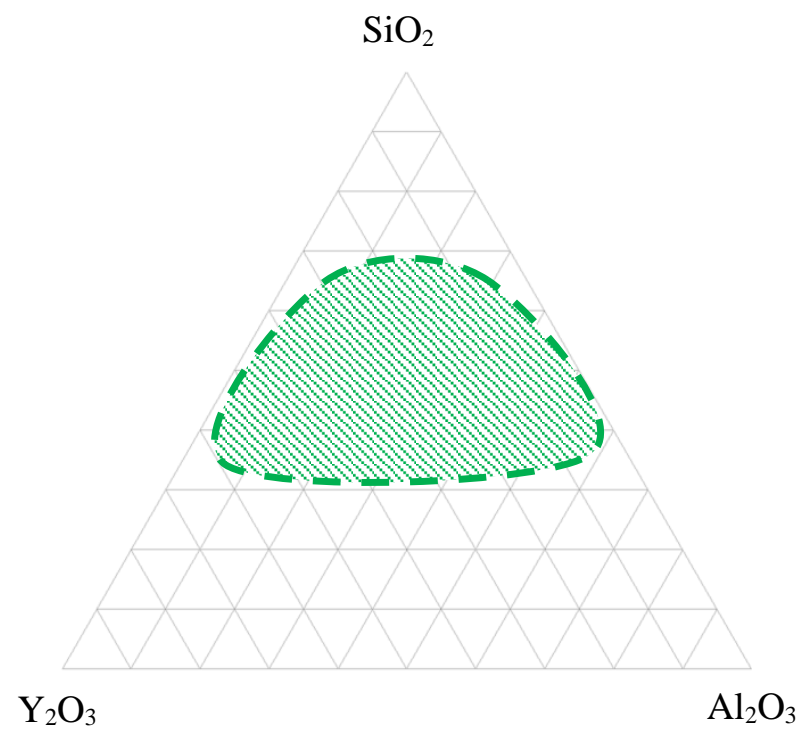

Fig. 1: Ternary phase diagram of the $\mathrm{YAS}\left(\mathrm{Y}_{2} \mathrm{O}_{3}-\mathrm{Al}_{2} \mathrm{O}_{3}-\mathrm{SiO}_{2}\right)$ system. The batch compositions investigated in this work are marked by area $(\mathrm{mol} \%)$.

\subsection{Analysis}

Prepared sample was tested according to the listed in Table 1. The surface of microstructure before and after plasma etching was analysed using a Field Emission Scanning Electron Microscope (FE-SEM, JEOL, JSM-6500F) with and energydispersive spectrometer (EDS). Etching rate of composition and materials that are Quartz, $\mathrm{Y}_{2} \mathrm{O}_{3}, \mathrm{Al}_{2} \mathrm{O}_{3}$ and YAS-frit coated $\mathrm{Al}_{2} \mathrm{O}_{3}$ was evaluated by weight loss before and after plasma etching.

Table 1: Parameters for anti-plasma test.

\begin{tabular}{|c|c|}
\hline Parameter & Condition \\
\hline Top RF Power, W & 900 \\
\hline Bottom RF Power, W & 200 \\
\hline $\mathrm{CF} 4, \mathrm{Sccm}$ & 30 \\
\hline Ar, Sccm & 10 \\
\hline $\mathrm{O} 2, \mathrm{Sccm}$ & 5 \\
\hline Temperature, ${ }^{\circ} \mathrm{C}$ & 30 \\
\hline Pressure, mTorr & 10 \\
\hline Operating time, $\mathrm{hr}$ & 10 \\
\hline
\end{tabular}

\section{Results and Discussion}

Degree of YAS frit crystallization and $\mathrm{Y}_{2} \mathrm{O}_{3}$ content were proportional to each other owing to decreasing bridgeoxygen that can be network forming as increased $\mathrm{Y}_{2} \mathrm{O}_{3}$ content. And effect of network forming oxide (NWF) was decreased 
to degree of crystallization as $\mathrm{Al}_{2} \mathrm{O}_{3}$ content $[7,8]$. It is evident that the degree of YAS frit crystallization strongly depends on its composition.

Fig. 3.1 presents the cross-section of fabricated YAS frit was coated on the surface of $\mathrm{Al}_{2} \mathrm{O}_{3}$ ceramics. Dense and thick YAS-frit coated layer was observed is shown Fig. 3.1, its layer thickness was around $80 \mu \mathrm{m}$. In the every samples, Y-Al-Si$\mathrm{O}$ glasses were obtained with crystalline of Y-Al-O and Y-Si-O. Is shown Fig. 3.2, YAS frit coated layer was joined strongly with $\mathrm{Al}_{2} \mathrm{O}_{3}$ ceramics.

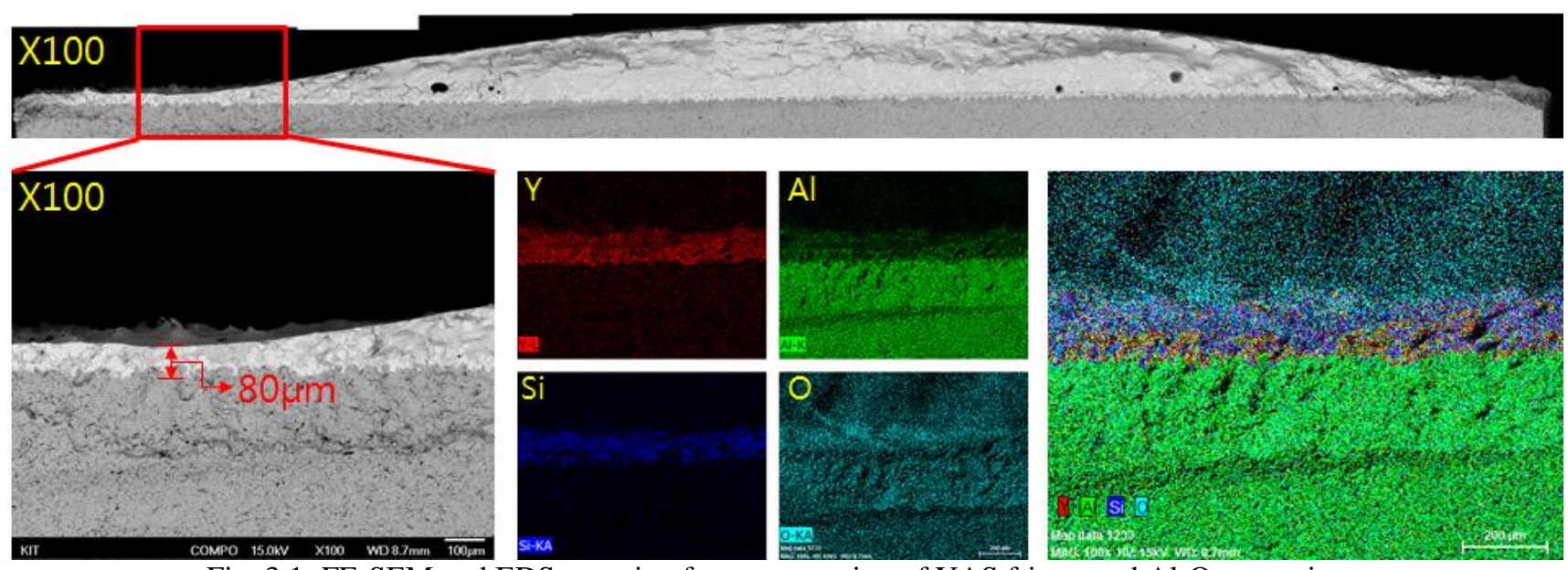

Fig. 3.1: FE-SEM and EDS mapping for cross-section of YAS frit-coated $\mathrm{Al}_{2} \mathrm{O}_{3}$ ceramics.
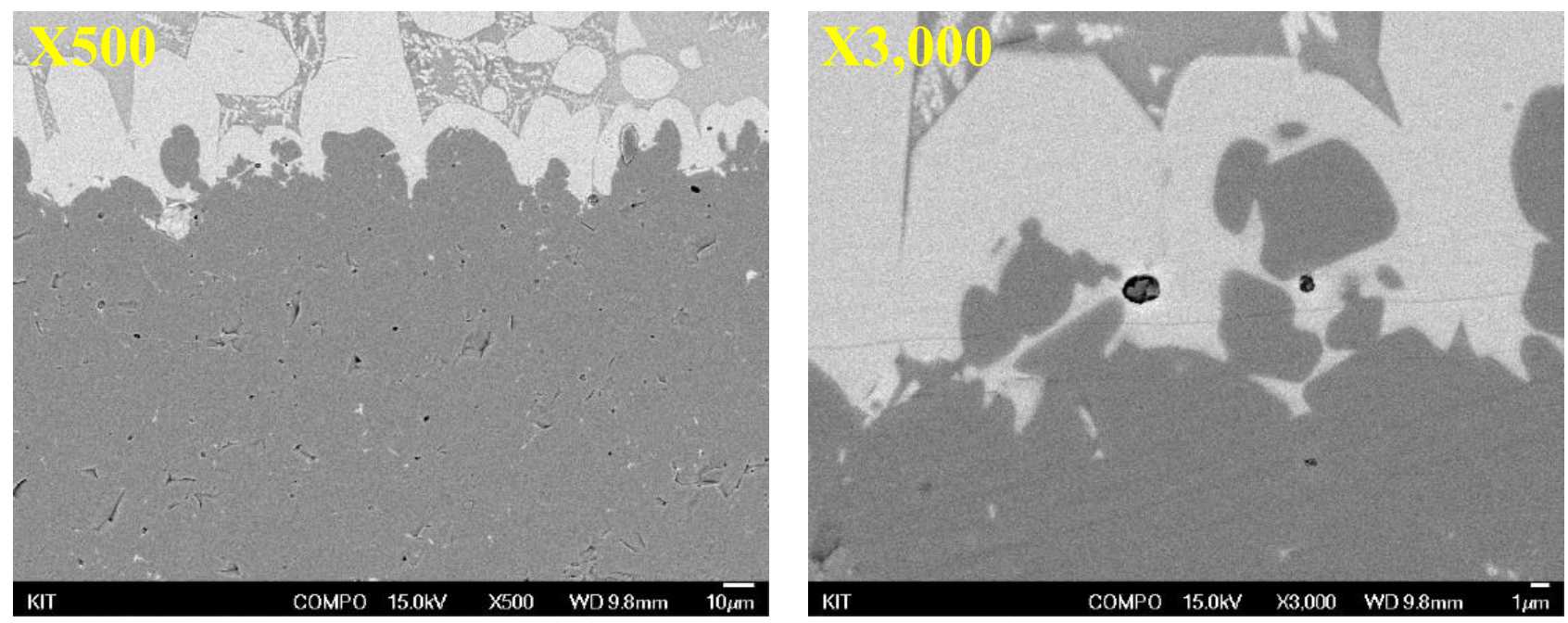

Fig. 3.2: FE-SEM image for joint interface of YAS frit-coated $\mathrm{Al}_{2} \mathrm{O}_{3}$ ceramics.

The plasma resistance and $\mathrm{Y}_{2} \mathrm{O}_{3}$ content were proportional to each other, composition of the highest $\mathrm{Y}_{2} \mathrm{O}_{3}$ content has highest plasma resistance. Fig. 4.1 presents comparison of the etching rates between commercial $\mathrm{Y}_{2} \mathrm{O}_{3}, \mathrm{Al}_{2} \mathrm{O}_{3}, \mathrm{Quartz}_{\mathrm{z}}$ that the most commonly used plasma resistant ceramic materials with YAS-frit coated $\mathrm{Al}_{2} \mathrm{O}_{3}$ ceramics. Plasma etching rates of the YAS-frit coated $\mathrm{Al}_{2} \mathrm{O}_{3}$ ceramics $(0.122 \%)$ was 6 times higher than quartz $(0.739 \%), 2$ times than $\mathrm{Al}_{2} \mathrm{O}_{3}(0.253 \%)$ and a half of $\mathrm{Y}_{2} \mathrm{O}_{3}(0.066 \%)$.

Is shown Fig. 4.2, comparison result between each materials using FE-SEM after anti-plasma test was shown that the quartz was chemically etched because of the chemical reaction between Si-element and fluorine gas and $\mathrm{Al}_{2} \mathrm{O}_{3}$ was physically etched. In $\mathrm{Y}_{2} \mathrm{O}_{3}$ material case, it nearly was not etched. In reality, It has been reported that the etch products are usually of the formula $\mathrm{SiF}_{\mathrm{x}}$ owing to be produced by the interaction between radicals or ions of fluorine gas and silicon atoms of the materials being etched[9,10]. Because of that the Quartz was rapidly etched by plasma than the $\mathrm{Y}_{2} \mathrm{O}_{3}, \mathrm{Al}_{2} \mathrm{O}_{3}$, and $\mathrm{YAS}$-frit coated $\mathrm{Al}_{2} \mathrm{O}_{3}$ ceramics. 


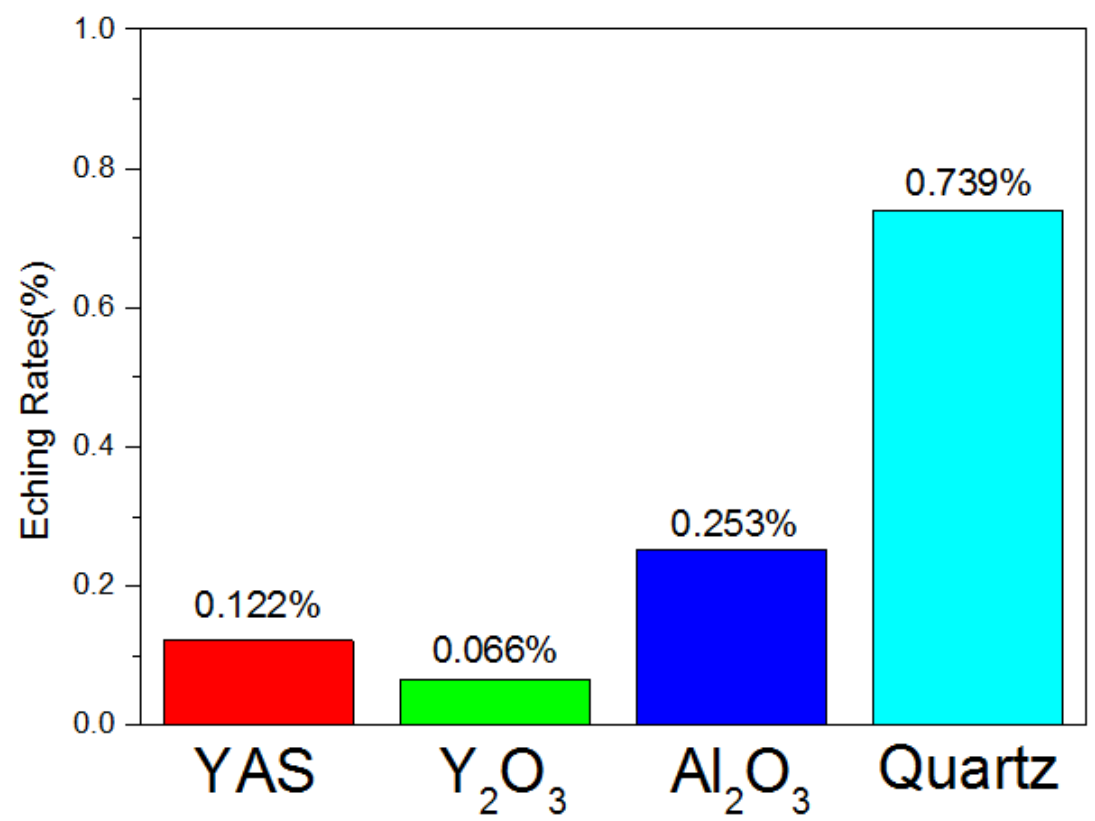

Fig. 4.1: Etching rates after fluorine plasma exposure for $10 \mathrm{hr}$ for $\mathrm{YAS}$ frit-coated $\mathrm{Al}_{2} \mathrm{O}_{3}, \mathrm{Y}_{2} \mathrm{O}_{3}, \mathrm{Al}_{2} \mathrm{O}_{3}$, Quartz, respectively.
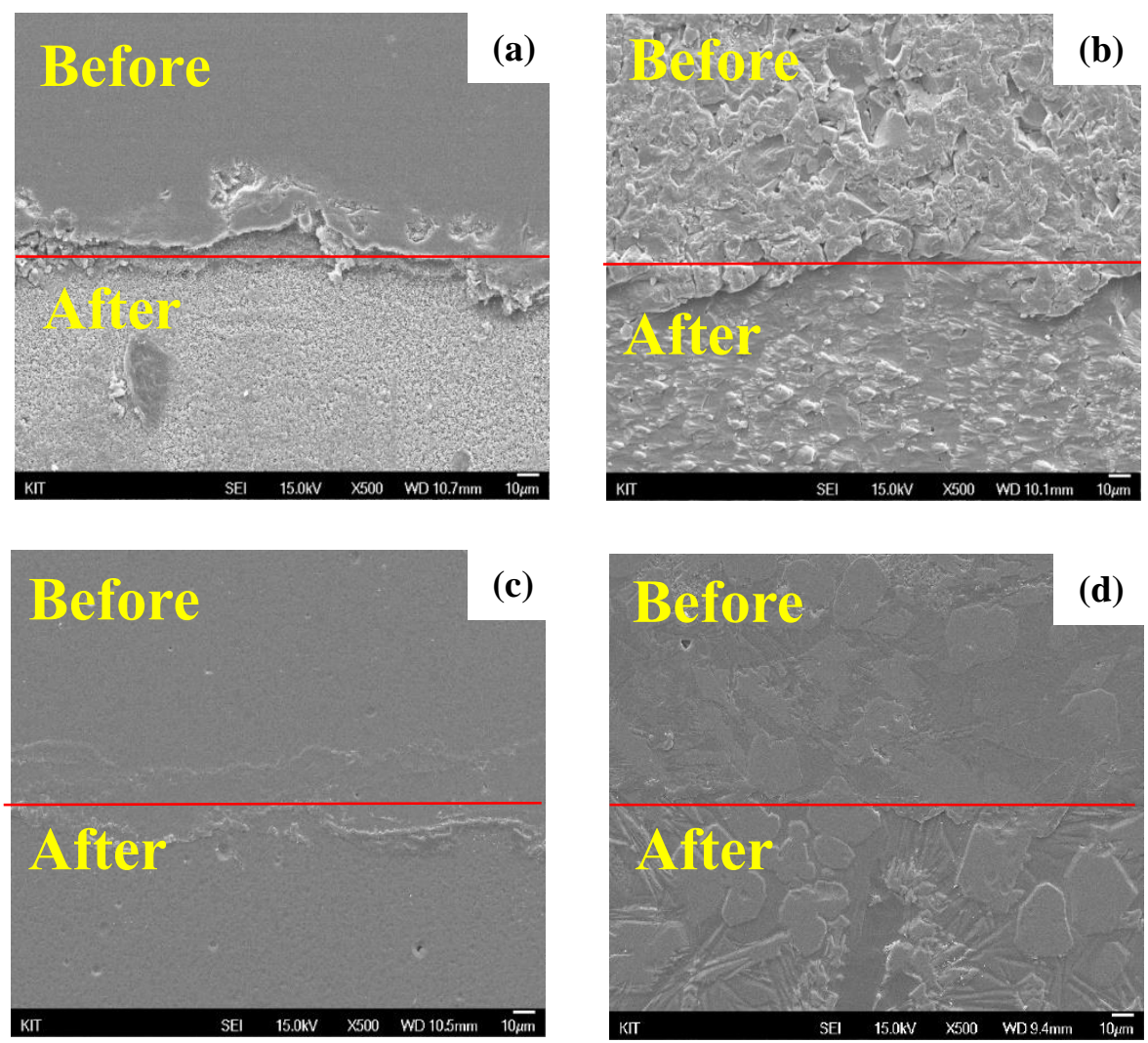

Fig. 4.2: FE-SEM images for (a) quartz, (b) $\mathrm{Al}_{2} \mathrm{O}_{3}$, (c) $\mathrm{Y}_{2} \mathrm{O}_{3}$, (d) YAS-frit coated $\mathrm{Al}_{2} \mathrm{O}_{3}$ after anti-plasma test.

\section{Conclusion}

The purpose of this study was to investigate that plasma resistance was improved by YAS frit coating on the surface of alumina ceramics. For this, fabricated YAS frit was coated on the alumina ceramics and then, plasma resistance was evaluated as each composition. The conclusions of the study were as follows. After YAS frit coated on the alumina ceramics, 
YAS frit became dense and thick coating layer $(\sim 80 \mu \mathrm{m})$ that was crystalline and amorphous of Y-Al-Si-O. The plasma resistance and $\mathrm{Y}_{2} \mathrm{O}_{3}$ content were proportional to each other, composition of the highest $\mathrm{Y}_{2} \mathrm{O}_{3}$ content has highest plasma resistance; its plasma resistance was 6 times higher than quartz, 2 times than $\mathrm{Al}_{2} \mathrm{O}_{3}$ and a half of $\mathrm{Y}_{2} \mathrm{O}_{3}$.

\section{References}

[1] G. S. May and C. J. Spanos, Fundamentals of Semiconductor Manufacturing and Process Control, John Wiley \& Sons, Inc., New Jerwey, 2006.

[2] D. M. Kim, Y. S. Oh, S. Kim, H. T. Kim, D. S. Lim, and S. M. Lee, "The Erosion Behaviors of $\mathrm{Y}_{2} \mathrm{O}_{3}$ and $\mathrm{YF}_{3}$ Coatings under Fluorocarbon Plasma,” Thin Solid Films, vol. 519, pp. 9698-9702, 2011.

[3] S. Jiansirisomboon, K. J. D. MacKenzie, S. G. Roberts, and P. S. Grant, "Low pressure plasma-sprayed $\mathrm{Al}_{2} \mathrm{O}_{3}$ and $\mathrm{Al}_{2} \mathrm{O}_{3} / \mathrm{SiC}$ nanocomposite coatings from different feedstock powders," J. Euro. Ceram. Soc., vol. 23, pp. 961-976, 2003.

[4] G. S. Selwyn, J. E. Heidenreich, and K. L. Haller, "Particle trapping phenomena in radio frequency plasma," Phys. Lett., vol. 57, pp. 1876-1878, 1990.

[5] T. J. Nho, K. K. Orr, J. K. Lee, and D. W. Kim, "Wetting behaviour of low temperature molten frits on various ceramic substrates," J. Kor, Ceram. Soc., vol. 20, no. 3, pp. 199-204, 1983.

[6] L. Wu, G. Liu, J. Li, B. He, Z. Yang, and Y. Chen, "Dependence of glass-forming ability on starting compositions in $\mathrm{Y}_{2} \mathrm{O}_{3}-\mathrm{Al}_{2} \mathrm{O}_{3}-\mathrm{SiO}_{2}$ system," Ceramics- Silikáty, vol. 55, no. 3, pp. 228-231, 2011.

[7] A. K. Varshneya, Fundamentals of Inorganic Glasses, 2nd Ed. Chapeltown: Society of Glass Technology, pp. 35-71 2012.

[8] J. E. Shelby, Introduction to Glass Science and Technology, 2nd Ed. Springer Verlag, pp. 7-11, 2005.

[9] K.-B. Kim, D. Kim, J. Lee, Y.-S. Oh, H.-T. Kim, H. Kim, and S.-M. Lee, "Erosion behavior of YAG ceramics under fluorine plasma and their XPS analysis," J. Kor. Ceram. Soc., vol. 46, no. 5, pp. 456-461, 2009.

[10] K. Kurihara, Y. Yamaoka, K. Karehashi, and M. Sekine, "Measurements of Desorbed Products by Plasma Beam Irradiation on $\mathrm{SiO}_{2}$," J. Vac. Sci. Technol. A, vol. 22, no. 6, pp. 2311-2314, 2004. 